\title{
Isparta İli Büyük Toprak Gruplarına Göre Tahıl Yetiștirilen Toprakların Bazı Özelliklerinin Belirlenmesi
}

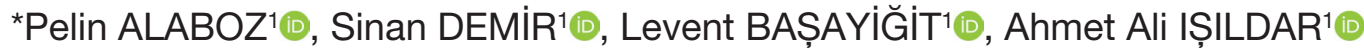 \\ ${ }^{1}$ Isparta Uygulamalı Bilimler Üniversitesi, Ziraat Fakültesi, Toprak Bilimi ve Bitki Besleme \\ Bölümü, Isparta, Türkiye
}

*Sorumlu yazar e-posta (Corresponding author e-mail): pelinalaboz@isparta.edu.tr

Geliș Tarihi (Received): 09.10.2019＜noBreak>＜noBreak>Kabul Tarihi (Accepted): 06.12.2019

\section{Öz}

Bu çalıșmada Isparta'da tahıl yetiștirilen toprakların özellikleri incelenmiș ve büyük toprak gruplarına bağlı olarak bazı toprak özellikleri yorumlanmıștır. Bu amaçla 6 farklı büyük toprak grubundan toplamda 150 noktadan yüzey $(0-30 \mathrm{~cm})$ örneklemesi yapılmıș, örneklerde kum, silt, kil, tarla kapasitesi, solma noktası, $\mathrm{pH}$, EC, organik madde, $\mathrm{CaCO}_{3}, \mathrm{~K}, \mathrm{Ca}, \mathrm{Mg}, \mathrm{Fe}, \mathrm{Cu}, \mathrm{Zn}, \mathrm{Mn}$ analizleri yapılmıștır. Analiz sonuçlarına göre; tahıl yetiștirilen tüm toprak grupları, nötr-hafif alkali reaksiyonlu, tuzsuz sınıfındadır. Bünye sınıfının \%78.5'i kumlu killi tın, ortalama tarla kapasitesi \%22.87, solma noktasının ise \%13.45 olarak belirlenmiștir. Organik madde içeriklerinin \%77.8'i düșük seviyelerde olan bu toprakların \%5'inde $\mathrm{Ca}$, \%7.85'inde $\mathrm{Mg}$, \%42'sinde Zn noksanlığı belirlenmiștir. Mn ve Cu yeterli iken, K ve Fe yeterli - fazla seviyede bulunmuștur. Minimum ve maksimum değerler göz önüne alındığında en fazla değișkenlik, tarla kapasitesi ve solma noktası için Kestanerengi topraklarda, pH ve EC için ise Kolüvyal topraklarda belirlenmiștir. Besin elementleri içerikleri yönünden Kestanerengi topraklarda herhangi bir noksanlığa rastlanılmamıștır. En fazla Mg ve Zn noksanlığının görüldüğü toprak grubu Kahverengi Orman toprakları olarak belirlenmiștir.

Anahtar Kelimeler: Toprak özellikleri, büyük toprak grupları, tahıl alanları

\section{Determination of Some Properties of Cereal Cultivated Soils Based on Great Soil Groups in Isparta Province}

\begin{abstract}
In this study, some properties of soils used for cereal cultivation were investigated and evaluated based on the great soil groups. For this purpose, surface soil samples $(0-30 \mathrm{~cm})$ were collected from 150 points in 6 different great soil groups. Sand, silt, clay, field capacity, wilt point, $\mathrm{pH}, \mathrm{EC}$, organic matter, $\mathrm{CaCO}_{3}, \mathrm{~K}$, $\mathrm{Ca}, \mathrm{Mg}, \mathrm{Fe}, \mathrm{Cu}, \mathrm{Zn}, \mathrm{Mn}$ of soil samples were analyzed. According to the results; all soil groups cultivated crops were neutral-slightly alkaline reactions. These soils had salt-free properties and $78.5 \%$ of soils were in sandy clay loam texture class. It was found that the average field capacity was $22.87 \%$ and wilting point was $13.45 \%$. Organic matter content was low at $77.8 \%$ of investigated soils. $\mathrm{Ca}, \mathrm{Mg}, \mathrm{Zn}$ deficiency in them were determined as $5 \%, 7.85 \%$ and $42 \%$, respectively. While $\mathrm{Mn}$ and $\mathrm{Cu}$ contents were sufficient level, $\mathrm{K}$ and Fe levels were sufficient-high in soils. When the minimum and maximum values were evaluated, the highest variability was determined in Chestnut soils for field capacity and wilting point, and Colluvial soils for $\mathrm{pH}$ and EC. Regarding their nutrient content, there was no deficiency in Chestnut soil groups. The highest $\mathrm{Mg}$ and $\mathrm{Zn}$ deficiency was determined in Brown Forest soil.
\end{abstract}

Keywords: Soil properties, large soil groups, cereal field

\section{Giriș}

Bilinçsiz ve yanlıș kullanımlar sonucu verimli tarım topraklarının giderek azalması ülke tarımını tehtit eden önemli sorunlardan birisidir. Ayrıca toprak besin elementi içeriğindeki değișimler, gereğinden fazla gübre ve ilaç kullanımı gibi etmenler ile topraklar verimsizleștirilmektedir. Sürdürülebilir bir tarım için toprağın üretkenliğinin devamının sağlanması oldukça önemlidir (Turan, Katkat, Özsoy ve Taban, 2010). Bitkilerin intiyaç 
duydukları besin elementleri ve beslenme durumlarının belirlenmesinde toprak analizleri en yaygın yöntemdir. Besin elementi yönünden uygun koșullar sağlanmıș olsa da toprağın diğer özellikleri (fiziksel, biyolojik, kimyasal) optimum olmadığı durumda yeterli ve dengeli beslenme sağlanamaz. Bunun sonucu olarak ürün veriminde istenilen sonuç elde edilememektedir. Geçmișten günümüze arazilerin verimlilik durumlarının belirlenmesi amaçlıçalışmalar yürütülmektedir (Bașar, 2001; Bașaran ve Okan, 2005; Çimrin ve Boysan, 2006; Demir ve Erdal, 2016; Doğan ve Erdal, 2018). Bu analizler yalnızca toprak verimliliğinin belirlenmesinde değil aynı zamanda planlamalarda da kullanılabilmektedir.

En önemli insan gıdası olan tahılların ülkemizdeki ekim alanı 11 milyon ha'dır. Ekim alanlarının \% 70'ini buğday, \%22'sini arpa \% 6 sını mısır \% 2'lik kısmını ise diğer tahıl ürünleri olușturmaktadır (Baydar, 2018; TÜiK, 2018). Tahıllarda verim artıșı, tohum kalitesi ve miktarıyla doğrudan ilișkili olup bu ilișkinin sağlanmasında toprak üretkenliği en önemli etkendir. Karasal iklimin hakim olduğu Isparta bölgesinde en fazla ekimi yapılan ürünler tahıllar olup bunlar içerisinde ise buğdayın payı oldukça yüksektir (Yılmaz, Demircan ve Dernek, 2006). Oldukça geniș alanda yapılan tahıl yetiștiriciliğinin daha iyi sürdürülebilmesi için toprakların özelliklerinin belirlenmesi oldukça önemlidir. Toprak özelliklerinin belirli bir toprak sınıflama sistemi içerisinde değerlendirilmesi verimlilik ve planlama çalıșmaları için önemli olmaktadır. Ülkemizde tüm topraklar için tanımlı olan eski Amerikan sistemi Büyük Toprak Gruplarına göre farklılıkların olduğu yapılan çalışmalarda ortaya konmuştur (Tümsavaș ve Aksoy, 2008; Turan, Katkat, Özsoy ve Taban, 2010; Sünal ve ark., 2018). Bu çalıșmada; Isparta ilinde tahıl yetiștiriciliği yapılan toprakların bazı fiziksel ve kimyasal özellikleri incelenerek büyük toprak gruplarına göre değişimleri değerlendirilmiştir.

\section{Materyal ve Yöntem}

Çalışma, Isparta Merkez, Atabey, Keçiborlu, Gönen, Eğirdir, Gelendost, Șarkikaraağaç, Yenișarbademli, Uluborlu, Sütçüler, Senirkent, Yalvaç ve Aksu ilçeleri içerisinde tahıl yetiștirilen arazileri kapsamıștır. Tahıl alanlarının \%37'si buğday, \%34'ü arpa \%1'i yulaf \%1'i ise çavdardır (TÜíK, 2018). Isparta ili, Akdeniz iklimi ile Orta Anadolu iklimi arasındaki geçiș bölgesinde yer almaktadır. Torosların güneyindeki çukur yerlerde ılıman, toroslara doğru yükseklik arttıkça daha serin ve yağıșlı bir iklim hüküm sürmektedir. Göller Bölgesi'nin merkezi konumunda olan il'de uzun yıllar ortalama yağış miktarı 564.8 mm'dir (MGM, 2018). Tașeli ve Tepeli platolarının sıkıșması sonucuda kıvrılmalar daha sonra ise tektonik ve volkanik hareketlerle șekiller olușmuștur. Bazalt ve trakit yatakları volkanik hareketler sonucu ortaya çıkmıș olup, en eski yapı paleozoik'e aittir. Karasal tortullașma, volkanizma ve blok faylanmaları ile göl yatağı güney-güney doğu kenarı fay üzerine yaslanmıştır (KHGM, 1994). İ yüz ölçümünün \%27.49'luk kısmı tarımsal, \%63.18'lik kısmı orman ve yarı doğal alanlardan, \%9.3'lük kısmı ise su kütleleri ile yapay bölgelerden olușmaktadır. Tarımsal alanların içerisinde; \%27.08 sulanmayan ekilebilir alan, \%21.56 doğal bitki örtüsü ile karıșık tarım alanlar, \%13.8 sürekli sulanan, \%13.69 sulanan karıșık tarım alanlar, \%10.01 sulanmayan karıșık tarım alanları, \%8.78 sulanana meyve, \%1.27 sulanmayan meyve, \%2.53 mera, $\% 1.1$ üzüm bağları ve $\% 0.17$ sürekli sulanana alanlar içindeki sera alanları olarak dağılım göstermektedir (Corine, 2018).

Tahıl yetiștirilen arazilerin topraklarından yüzey örneklemesi $(0-30 \mathrm{~cm})$ yapılmıștır. Örnekleme noktalarının seçiminde; $1 / 25.000$ ölçekli toprak haritası kullanılmıș ve il'deki yaygın büyük toprak gruplarını temsil etmesi hedeflenmiștir. Böylece toplamda 150 noktadan bozulmuș yüzey toprak örneği alınmıștır. Örneklerin \%52.7'si buğday, \%40.4'ü arpa, \%1.3'si çavdar \%5.5'i ise yulaftır. Toprak örneklerinin dağılımları ve büyük toprak gruplarına (BTG) göre dağılımı Şekil 1'de belirtilmiștir. Arpa'nın; \%25'i Kahverengi Orman, \%17.3'ü Kırmızı Kahverengi Akdeniz, \%17.3'ü Kestanerengi, \%15.4'ü Kireçsiz Kahverengi Orman, \%13.5'i Kolüvyal, \%11.5'i Alüvyal buğday; \%18.5'i Kahverengi Orman, \%15.2'si Kırmızı Kahverengi Akdeniz, \% 20.7'si Kestanerengi, \% 18.5'i Kireçsiz Kahverengi Orman, \%13'ü Kolüvyal, \%14.1'i Alüvyal, 

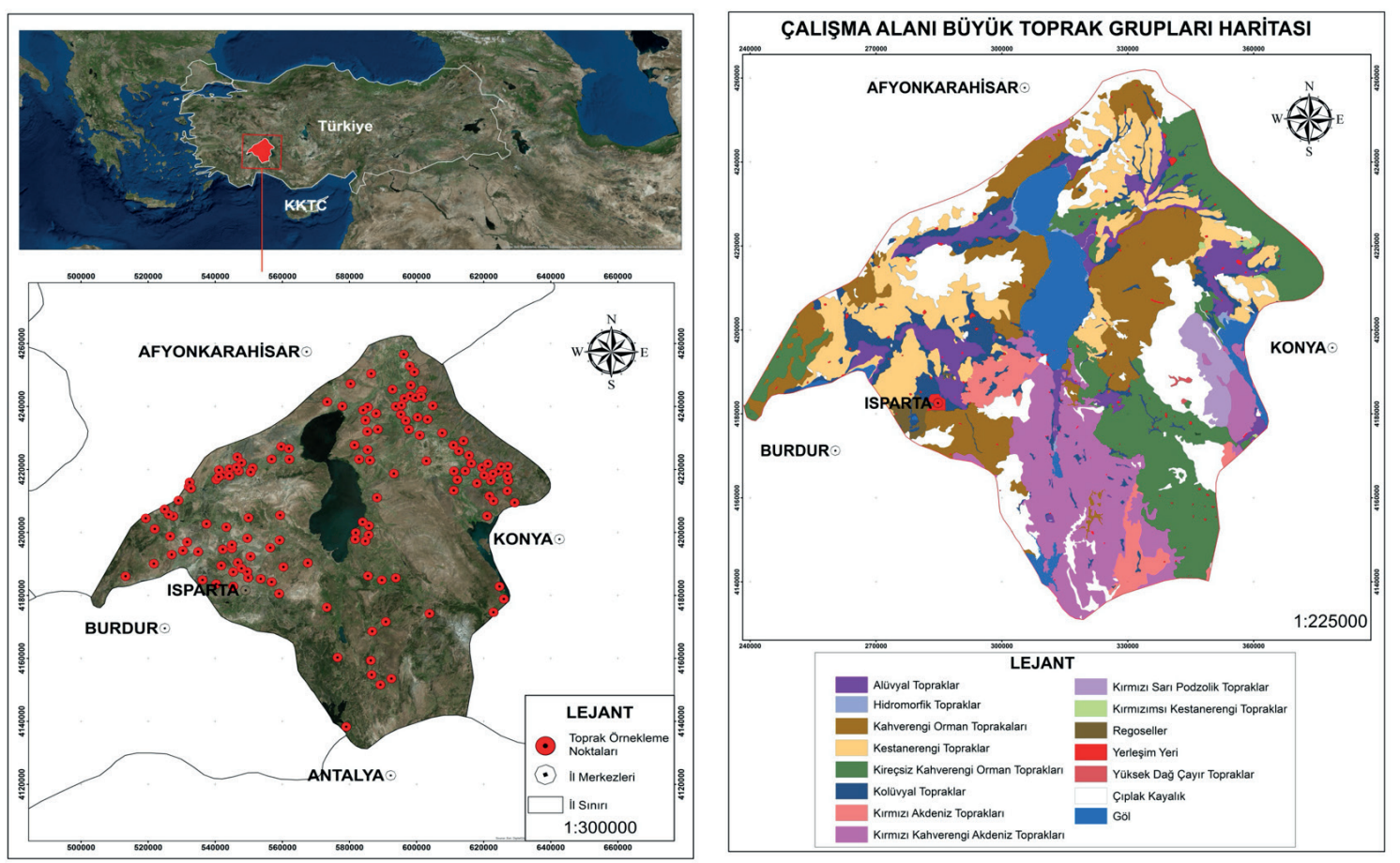

Șekil 1. Toprak örnekleme noktalarının dağılımı ve büyük toprak grupları haritası

Figure 1. Distribution of soil sampling points and map of large soil groups

çavdar; \%33.3'ü Kırmızı Kahverengi Akdeniz, \%33.3'ü Kestanerengi, \%33.3'ü Alüvyal, yulaf; \%33.3'ü Kırmızı Kahverengi Akdeniz, \%33.3'ü Kestanerengi, \%33.3'ü Kolüvyal toprak gruplarında yetiștirilmektedir.

Çizelge 1. Büyük toprak gruplarının alansal dağılımı Table 1. Spatial distribution of soil groups

\begin{tabular}{|c|c|c|c|c|}
\hline \multirow{2}{*}{ AÇIKLAMASI } & \multirow{2}{*}{ ÖRNEK SAYISI } & \multirow{2}{*}{ SEMBOL } & \multicolumn{2}{|c|}{ BTG } \\
\hline & & & Alan $\left(\mathrm{km}^{2}\right)$ & Alan (\%) \\
\hline Kahverengi Orman Toprakları & 30 & $\mathrm{M}$ & 1400.02 & 15.73 \\
\hline Kırmızı Kahverengi Akdeniz Topraklar & 25 & $E$ & 1198.53 & 13.46 \\
\hline Kestanerengi Topraklar & 30 & CE & 1197.86 & 13.46 \\
\hline Kireçsiz Kahverengi Orman Toprakları & 25 & $\mathrm{~N}$ & 903.04 & 10.14 \\
\hline Kolüvyal Topraklar & 20 & $\mathrm{~K}$ & 570.03 & 6.40 \\
\hline Alüvyal Topraklar & 20 & A & 514.76 & 5.78 \\
\hline Kırmızı Akdeniz Toprakları & & $\mathrm{T}$ & 280.14 & 3.15 \\
\hline Kırmızı Sarı Podzolik Topraklar & & $P$ & 160.42 & 1.80 \\
\hline Regoseller & & L & 53.6 & 0.60 \\
\hline Yerleșim Alanı & & YR & 52.29 & 0.59 \\
\hline Hidromorfik Alüvyal Topraklar & & $\mathrm{H}$ & 22.62 & 0.25 \\
\hline Kırmızımsı Kestanerengi Topraklar & & $D$ & 13.29 & 0.15 \\
\hline Yüksek Dağ Çayır Topraklar & & Y & 6.19 & 0.07 \\
\hline Çıplak Kayalık & & CK & 1400.20 & 15.73 \\
\hline Göl & & Göl & 589.91 & 6.63 \\
\hline \multirow[t]{2}{*}{ Kireçsiz Kahverengi Topraklar } & & $U$ & 538.92 & 6.05 \\
\hline & & TOPLAM & 4922.61 & 100.00 \\
\hline
\end{tabular}

Örneklerin Büyük Toprak Gruplarına göre dağılımı ve Büyük Toprak Gruplarının il arazilerindeki oranları Çizelge 1'de belirtilmiștir. Örnekleme noktaları çıplak kayalık ve göl dışında kalan diğer toprak gruplarının \% 83.43’lük bir kısmını temsil etmektir. 
Çizelge 2. Analiz yöntemleri

Table 2. Methods of analysis

\begin{tabular}{|c|c|c|c|}
\hline Özellik & Birim & Yöntem & Kaynak \\
\hline $\begin{array}{l}\text { Tarla kapasitesi (TK)- } \\
\text { Solma noktası (SN) }\end{array}$ & $\begin{array}{c}\% \\
(\mathrm{~m} / \mathrm{m})\end{array}$ & 0.33 ve 15 bar'da tutulan su içeriği & Demiralay, 1993 \\
\hline Tekstür & $\%$ & Hidrometre yöntemi & \\
\hline $\begin{array}{l}\text { Elektriksel iletkenlik } \\
\text { (EC) }\end{array}$ & $\mu \mathrm{S} / \mathrm{cm}$ & Toprak su süspansiyonu & $\begin{array}{l}\text { US. Salinity Laboratory } \\
\text { Staff, } 1954\end{array}$ \\
\hline Organik madde & $\%$ & Modifiye edilmiș Walkley-Black & \\
\hline $\mathrm{pH}$ & $1: 2.5$ & Toprak su süspansiyonu & \\
\hline $\mathrm{CaCO}_{3}$ & $\%$ & Scheibler kalsimetresi & Kacar, 2009 \\
\hline $\mathrm{K}, \mathrm{Ca}, \mathrm{Mg}$ & $\mathrm{mg} \mathrm{kg}^{-1}$ & Amonyum asetat ekstraksiyonu & \\
\hline $\mathrm{Fe}, \mathrm{Cu}, \mathrm{Zn}, \mathrm{Mn}$ & $\mathrm{mg} \mathrm{kg}^{-1}$ & DTPA ektraksiyonu & \\
\hline
\end{tabular}

Toprak örneklerinin bazı fiziksel (kum, silt, kil, tarla kapasitesi, solma noktası ), kimyasal $(\mathrm{pH}$, EC, kireç, organik madde, ekstrakte edilebilir $\mathrm{Ca}, \mathrm{Mg}, \mathrm{K}, \mathrm{Fe}, \mathrm{Cu}, \mathrm{Zn}, \mathrm{Mn}$ ) özellikleri Çizelge 2'de belirtilen yöntemlere göre belirlenmiștir. Toprak analiz sonuçlarının değerlendirilmesi Richards 1954; Lindsay ve Norvell 1969; Follet 1969; Maas 1986; FAO 1990; TOVEP 1991; Güneș, Aktaș, İnal ve Alpaslan, 1996; Kacar, (2009)'a göre yapılmıștır (Çizelge 3). Toprak örneklerinin tanımlayıcı istatistikleri Minitap 16 paket programı kullanılarak değerlendirilmiștir. Verileri normal dağılımı Kolmogorov-
Smirnov testi (Karaatlı 2010) ile kontrol edilmiștir. Verilerin BTG'ye göre dağılımlarının gösterilmesinde Box plot grafiklerinden yararlanılmıștır. Haritalar ve örnekleme noktalarının konumsal değerlendirmesinde ArcGIS yazılımı kullanılmıștır.

\section{Bulgular ve Tartıșma}

Isparta ili tahıl yetiștirilen alanlara özgü toprakların tanımlayıcı istatistikleri Çizelge 4'de belirtilmiștir. Toprakların kum, silt, kil içerikleri \%9.37-67.39, \%10.03-71.38, \% 10.21-49.49

Çizelge 3. Toprak özelliklerinin sınıflandırıması

Table 3. Classification of soil properties

\begin{tabular}{|c|c|c|c|c|c|c|}
\hline Özellik & Çok az & $A z$ & Yeterli & Fazla & Çok fazla & \\
\hline $\mathrm{K}\left(\mathrm{mg} \mathrm{kg}^{-1}\right)$ & $<50$ & $50-140$ & $140-370$ & $370-1000$ & $>1000$ & \\
\hline $\mathrm{Ca}\left(\mathrm{mg} \mathrm{kg}^{-1}\right)$ & $0-380$ & $380-1150$ & $1150-3500$ & $3500-10000$ & $>10000$ & \\
\hline $\mathrm{Mg}\left(\mathrm{mg} \mathrm{kg}^{-1}\right)$ & $0-50$ & $50-160$ & $160-480$ & $480-1500$ & $>1500$ & \\
\hline $\mathrm{Mn}\left(\mathrm{mg} \mathrm{kg}^{-1}\right)$ & $<4$ & $4-14$ & $14-50$ & $50-170$ & $>170$ & \\
\hline \multirow[t]{2}{*}{$\mathrm{Zn}\left(\mathrm{mg} \mathrm{kg}^{-1}\right)$} & $<0.2$ & $0.2-0.7$ & $0.7-2.4$ & $2.4-8.0$ & $>8.0$ & \\
\hline & $\mathrm{Az}$ & Orta & Fazla & & & \\
\hline \multirow[t]{2}{*}{$\mathrm{Fe}\left(\mathrm{mg} \mathrm{kg}^{-1}\right)$} & $<0.2$ & $0.2-4.5$ & $>4.5$ & & & \\
\hline & Yetersiz & Yeterli & & & & \\
\hline \multirow[t]{2}{*}{$\mathrm{Cu}\left(\mathrm{mg} \mathrm{kg}^{-1}\right)$} & $<0.2$ & $>0.2$ & & & & \\
\hline & Kireçsiz & Az kireçli & Orta kireçli & Kireçli & Çok kireçli & Çok fazla kireçli \\
\hline \multirow[t]{2}{*}{$\mathrm{CaCO}_{3}(\%)$} & $0-2$ & $0-4$ & $4-8$ & 8-15 & $15-50$ & $>50$ \\
\hline & Tuzsuz & Hafif Tuzlu & Orta Tuzlu & Çok Tuzlu & & \\
\hline \multirow[t]{2}{*}{$\mathrm{EC}\left(\mathrm{dSm}^{-1}\right)$} & $<2$ & $2-4$ & $4-8$ & $8-15$ & & \\
\hline & Çok az & $A z$ & Orta & İyi & Yüksek & \\
\hline \multirow[t]{2}{*}{$\mathrm{OM}(\%)$} & $0-1$ & $1-2$ & $2-3$ & $3-4$ & $>4$ & \\
\hline & Kuvvetli Asit & Orta Asit & Hafif Asit & Nötr & Hafif Alkali & Kuvvetli Alkali \\
\hline $\mathrm{pH}$ & $<4.5$ & $4.5-5.5$ & $5.5-6.5$ & $6.5-7.5$ & $7.5-8.5$ & $>8.5$ \\
\hline
\end{tabular}


Çizelge 4. Tahıl yetiștirilen toprakların bazı fiziksel kimyasal toprak özellikleri

Table 4. Some physical chemical properties of cereal soils

\begin{tabular}{|c|c|c|c|c|c|c|}
\hline Özellikler & Minimum & Maksimum & Ortalama & $\begin{array}{l}\text { Varyasyon } \\
\text { katsayısı }\end{array}$ & Çarpıklık & Basıklık \\
\hline Kum (\%) & 9.37 & 67.39 & 51.15 & 24.87 & -1.49 & 1.76 \\
\hline Silt (\%) & 10.03 & 71.38 & 23.02 & 53.03 & 1.91 & 1.77 \\
\hline Kil (\%) & 10.21 & 49.49 & 25.83 & 18.87 & 0.50 & 2.00 \\
\hline $\mathrm{pH}$ & 6.89 & 8.16 & 7.57 & 3.44 & -0.26 & -0.27 \\
\hline $\mathrm{EC}(\mu \mathrm{S} / \mathrm{cm})$ & 81.00 & 678 & 214.16 & 47.01 & 1.73 & 3.80 \\
\hline $\mathrm{CaCO}_{3}(\%)$ & 1.01 & 55.57 & 14.04 & 98.48 & 0.94 & -0.29 \\
\hline Organik Madde (\%) & 0.49 & 3.72 & 1.60 & 44.93 & 0.99 & 0.79 \\
\hline Tarla Kapasitesi (\%) & 15.24 & 32.80 & 22.87 & 16.69 & 0.19 & -0.42 \\
\hline Solma Noktası (\%) & 7.23 & 22.12 & 13.45 & 23.13 & 0.52 & -0.01 \\
\hline $\mathrm{K}\left(\mathrm{mg} \mathrm{kg}^{-1}\right)$ & 280 & 998 & 609.20 & 32.58 & 0.37 & -0.78 \\
\hline $\mathrm{Ca}\left(\mathrm{mg} \mathrm{kg}^{-1}\right)$ & 1003 & 8917 & 4945 & 35.51 & -0.14 & -0.31 \\
\hline $\operatorname{Mg}\left(\mathrm{mg} \mathrm{kg}^{-1}\right)$ & 137.3 & 1487 & 650 & 72.29 & 0.82 & -0.97 \\
\hline $\mathrm{Fe}\left(\mathrm{mg} \mathrm{kg}^{-1}\right)$ & 1.15 & 6.93 & 4.11 & 32.85 & 0.15 & -0.48 \\
\hline $\mathrm{Cu}\left(\mathrm{mg} \mathrm{kg}^{-1}\right)$ & 0.45 & 3.22 & 1.76 & 31.71 & 0.15 & -0.48 \\
\hline $\mathrm{Zn}\left(\mathrm{mg} \mathrm{kg}^{-1}\right)$ & 0.31 & 2.41 & 0.88 & 55.73 & 1.61 & 2.05 \\
\hline $\mathrm{Mn}\left(\mathrm{mg} \mathrm{kg}^{-1}\right)$ & 17.05 & 42.31 & 28.052 & 20.05 & 0.47 & -0.58 \\
\hline
\end{tabular}

arasında değișim göstermiștir. Tahıl yetiștirilen alanların \% 9.2 killi tın, \% 2.8 siltli kil, \% 3.6 siltli tın, \% 5 tın, \% 78.5 kumlu killi tın, \% 0.7 kil bünye sınıfında olduğu belirlenmiștir. Kil fraksiyonları tane büyüklüğü bakımından küçük fakat yüzey alanı bakımından büyük olduğundan bitki gelișiminde önemli rol oynamaktadir. Azlan, Aweng, Ibrahim ve Noorhaidah (2012) tarafından, killi topraklarda organik maddenin parçalanma hızının daha yavaş olduğu bildirilmiştir. Toprak reaksiyonu (pH) nötr (6.89)-hafif alkali (8.16) arasında değișim göstermekte olup tuzluluk sorunu bulunmamaktadır. \% $\mathrm{CaCO}_{3}$ içerikleri kireçsiz (\% 1.01) çok fazla kireçli (\%55.57) sınıfında belirlenmiștir. Alanda, toprakların $\mathrm{pH}$ ve kireç içeriklerinin yüksek olması bitki besin elementlerinin alınımını ve yarayıșıılı̆ını negatif yönde etkilemektedir (Schachtschabel, Blume, Brümmer, Hartge ve Schwertmann, 2001). $\mathrm{CaCO}_{3}$ 'ün $\mathrm{pH}$ seviyesinde artıșa yol açacağı Rice (1999) tarafından da belirtilmiștir. Ayrıca düșük pH'da çözünebilir tuz miktarı artmaktadır. (Mohd-Aizat, Mohamad-Roslan, Sulaiman ve Karam, 2014; Budak, Günal, Çelik, Acır ve Sırrı, 2018). Bölgede kireç taşı ve dolamitin hakim olması (Bilgin ve Kara, 2019) \% $\mathrm{CaCO}_{3}$ 'ün yüksekliğinin bir sebebi niteliğindedir. Tüm toprakların organik madde içeriklerinin dağılımları incelendiğinde \% 21.4 çok az, \% 56.4 az, \% 15 orta, $\% 7.2$ 'si iyi seviyelerdedir. Güçdemir (2006) tarafından göller bölgesi topraklarının \% 65 'inin organik madde içeriklerinin az (\% 0-2) seviyelerde olduğun bildirilmiștir. Organik madde kil yüzeyine bağlanmakta ve agregat olușturmaktadır (Baldock, 2007). Organik materyalin artmasına bağlı toprağın su tutma kapasitesi artmakta ayrıca strüktür olușumu olumlu yönde etkilenerek agregatların dayanımını artmaktadır (Aydemir, Akgül, Canbolat ve Ișıldar, 2005).

Doğan ve Erdal (2018) Burdur ili tahıl yetiștirilen toprakların kireç içeriklerinin yüksek organik madde içeriklerinin ise düșük seviyelerde olduğunu belirtmișlerdir. Toprakların tarla kapasitesi içerikleri \%15.2432.80 , solma noktası ise \%7.23-22.12 arasında belirlenmiștir. Ortalama tarla kapasitesi seviyesi \% 23.87 solma noktası ise \% 13.45'dir. Çalıșma alanlarının \%78.5'lik kısmı kumlu killi tın bünye sınıfı içerisinde yer almaktadır. Rawls, Brakensiek ve Saxton (1982), kumlu killi tın bünyeli toprakların tarla kapasitelerini \%18.8$32.4(\mathrm{v} / \mathrm{v})$ solma noktalarını ise $\% 8.5-21.1(\mathrm{v} / \mathrm{v})$ olarak sınıflamıștır. Tarla kapasitesi ile solma noktası arasında yaklașık $1.77^{\prime}$ lik bir oran 
belirlenmiștir. Diallo ve Mariko (2013) tarafından tarla kapasitesi ile solma noktası arasındaki oranın 1.6 olduğu bildirilmiștir. Toprakların tarla kapasitesi ve solma noktasındaki nem içerikleri; tekstür, organik madde ve strüktüre bağlı olarak değișim göstermekte olup tane büyüklüğünün küçülmesi, organik madde içeriğinin artması ve strüktürün iyileșmesi ile söz konusu nem sabitelerinde tutulan nem miktarı artmaktadır (Karahan, Erșahin ve Öztürk, 2014).

Örneklerde değișebilir K içerikleri 280$998 \mathrm{mg} \mathrm{kg}^{-1}$ arasında değișmekte olup $\% 13.57$ 'sinde yeterli, \% 86.42'sinde fazla seviyeler $\mathrm{K}$ belirlenmiștir. \%5'i az, \%20 'si yeterli, \%75'i fazla $\mathrm{Ca}$ içeren toprakların konsantrasyonları 1003-8917 $\mathrm{mg} \mathrm{kg}^{-1}$ arasında değișim göstermiștir. Mg içerikleri 137.30$1487 \mathrm{mg} \mathrm{kg}^{-1}$ arasında olan toprakların \% 7.85'i az, \%47.14'ü yeterli, \%45.01 fazla seviyelerde bulunmuștur. Toprakların tamamında yeterli seviyede $\mathrm{Mn}$ (17.05-42.31 $\left.\mathrm{mg} \mathrm{kg}^{-1}\right)$ ve $\mathrm{Cu}(0.45-$ $3.22 \mathrm{mg} \mathrm{kg}^{-1}$ ) belirlenmiștir. \%65'i orta, \%35'i fazla seviyede $\mathrm{Fe}\left(1.15-6.93 \mathrm{mg} \mathrm{kg}^{-1}\right)$ içeren toprakların, Zn içeriklerinin (0.31-2.41 $\left.\mathrm{mg} \mathrm{kg}^{-1}\right)$ \%42'si az, \%58'i yeterli bulunmuștur. Nitekim bölgede toprakta ekstrakte edilebilir (DTPA) Fe içerikleri 3.4-18.4 mg kg$~^{-1}$ arasında olduğu belirtilmiștir (Boydak ve Erdal, 2011). Benzer olarak bölge topraklarında organik madde içerikleri \%0.56 - 3.85, $\mathrm{pH}^{\prime} 6.46$ - 8.46, EC' 0.39 - $4.04\left(\mathrm{ds} \mathrm{m}^{-1}\right), \mathrm{CaCO}_{3}$ içerikleri ise \%0.01 - 50 aralığında değișim gösterdiği belirtilmiștir (Bașayiğit, Șenol ve Müjdeci, 2008). Bilgin ve Kara (2019), bölgenin volkanik kökenli kayaçlar ile feldispat minerallerince zengin olduğunu bildirmiștir. Feldispatlar, farklı oranlarda değișebilir katyonlar $(\mathrm{Ca}, \mathrm{Mg}, \mathrm{K})$ içeren susuz üç boyutlu alüminosilikatlardır. Feldispatlar toprağın ana materyali ve parçalanma ayrıșma durumuna göre $\mathrm{Na}, \mathrm{K}, \mathrm{Ca}, \mathrm{Cu}, \mathrm{Pb}, \mathrm{Rb}$, Cs gibi elementlerin kaynağını olușturur. Bölgenin bazı volkanik alanlarında Pomza hakimdir. Pomza tașlarında; albit, biyotit, piroksen gibi mineraller gözlenmektedir (Çelik, 2006). Piroksenler tek zincirli ferro magnezyum mineralleri olup, Biyotit magnezyum- demir mikaları Albit ise Na- feldispatıdır. Bölgede söz konusu mineralin hakim olması incelenen katyonlarda noksanlığa rastlanılmamasının bir sebebidir.
Çarpıklık katsayısının negatif olması sola, pozitif olması sağa çarpıklı̆ı̆ gösterirken basıklık katsayısında ise negatif, eğrinin normale göre daha basık, pozitiflik daha dik olduğunun göstergesidir. Çarpıklık ve basıklık katsayılarının 0'a yakın olması normal dağılım olduğunun bir göstergesidir. Söz konusu parametrelerin \pm 2 sınırları içerisinde bulunması normal bir dağılım olarak kabul görmektedir (Howitt ve Cramer, 2011). Bu örnekler üzerinde elde edilen veriler normal dağılım göstermiștir. Toprak özelliklerindeki değișkenliği belirlemede kullanılan varyasyon katsayısı Wilding (1985)'e göre düșük $(<\% 15)$, orta $(<\% 35)$ ve yüksek (>\%35) olarak sınıflandırılmıștır. İncelenen özellikler arasında pH "düșük", kum, kil, TK, $\mathrm{SN}, \mathrm{K}, \mathrm{Ca}, \mathrm{Fe}, \mathrm{Cu}, \mathrm{Mn}$ "orta" diğer özellikler ise "yüksek" değișkenlik göstemiștir. Topraklarda pH değișim aralığının geniș olmaması değișkenlik katsayısının düșük çıkmasının bir sebedir. Bașayiğit, Șenol ve Müjdeci, (2008) varyasyon katsayısını en düșük $\mathrm{pH}$, en yüksek EC ve kireç özelliklerinde tespit etmiș olup bu çalıșmada da benzer sonuçlar elde edilmiștir. Bölgenin toprak ana materyali, iklim ve topoğrafik karakteristiklerindeki farklııklar nedeniyle belirlenen toprak özellikleri için değișim aralığının geniș olması varyasyon katsayısının orta ve yüksek seviyelerde belirlenmesine yol açmıștır.

Toprakların pH, EC, OM ve $\mathrm{CaCO}_{3}$ içeriklerinin büyük toprak gruplarına göre değișimi Șekil 2'de verilmiștir. Topraklardaki $\mathrm{pH}$ ve EC değișim aralığı en geniș topraklar Koluviyaller olmuștur. Alüviyal topraklarda $\mathrm{pH}$ değișimidararalıktabulunmuștur. Geneldağılım 7.23 ile 7.92 arasında $\mathrm{pH}$ değerlerine sahip olan topraklarda alt (7.03) ve üst (8.01) aykırı değerler bulunmaktadır. Kolüvyal topraklar; dağlık ve tepelik arazilerin eteklerinde dar vadi tabanlarında yer çekimi ve küçük akıntılarla sürüklenmiș tanelerin birikimiyle olușmaktadır. Tașındıkları materyale göre toprak özellikleri değișim göstermekte olup bölgenin \% 6.4'lük kısmını kaplamaktadır (KHGM, 1994). Arpa ve buğday'ın yaklașık \%10-15 arasında Kolüvyal ve Alüvyal topraklarda yetiștirildiği bu toprakların nötr-hafif alkalin reaksiyonlu olduğu belirlenmiștir.

Tașınan sediment materyalin çeșitliliği kaynaklı olarak incelenen özelliklerde, değișim 

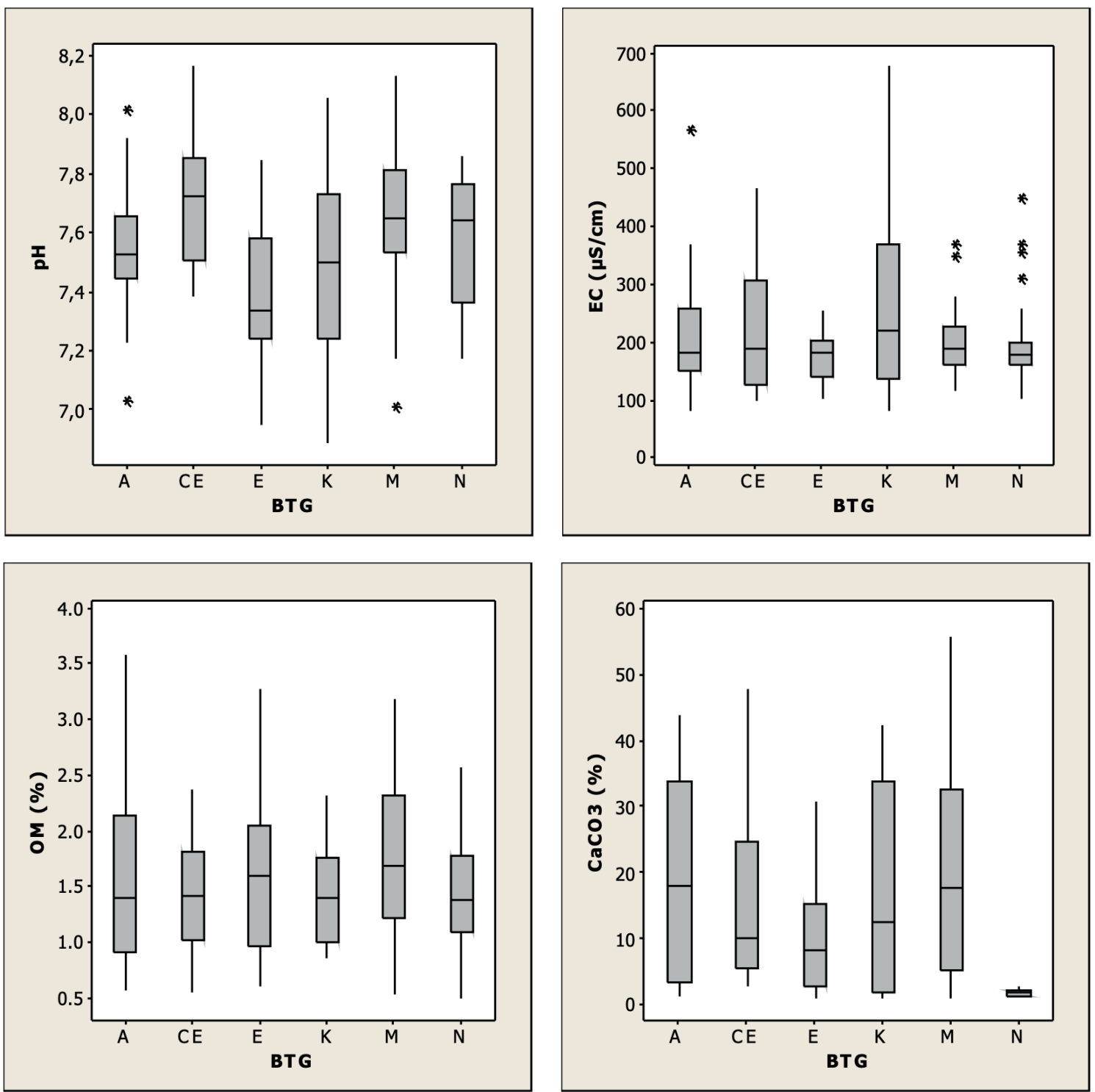

Șekil 2. $\mathrm{pH}, \mathrm{EC}, \mathrm{OM}$ ve $\mathrm{CaCO}_{3}$ içeriklerinin toprak gruplarına göre değișimi

Figure 2. Variation of $\mathrm{pH}, \mathrm{EC}, \mathrm{OM}$ and $\mathrm{CaCO}_{3}$ contents according to soil groups

aralığının geniș olması beklenilen bir sonuçtur (Dengiz, 2010). EC içerikleri incelendiğinde tüm toprak grupları için belirlenen ortanca değerler birbirine oldukça yakın iken en düșük değișim aralığı ve içerikler Kırmızı Kahverengi Akdeniz topraklarında belirlenmiștir. Arpa ve buğday'ın yaklașık \%15'i Kırmızı Akdeniz topraklarında yetiștirilmektedir. Kırmızı Kahverengi Akdeniz topraklar bölge topraklarının \%13.46'lık kısmını olușturmaktadır. Bu topraklar Kırmızı Akdeniz ve Kahverengi toprak grubunun karıșımıyla olușmuș $A B C$ profillerine sahiptirler. İlit ve kaolinit gibi kil minerallerinin hakim olduğu alanlarda baz doygunluğu \%35'den fazladır (KHGM, 1994). Aylar (2015), Kolüvyal toprakların genellikle orta bünyeli hafif alkalin reaksiyonlu olduğunu belirtirken Kolüvyal ve Alüvyal ana material üzerinde olușmuș topraklarda çalıșan Sünal ve ark. (2018), varyasyon katsayısını en düșük pH (\%7.9) en yüksek ise $\mathrm{CaCO}_{3}$ (\%86.7) içeriğinde belirlemișlerdir.

Tüm toprak gruplarının organik madde içerikleri incelendiğinde ortanca değerler birbirine yakın seviyelerde iken en büyük değișim aralığı Alüviyal topraklarda (\%0.583.72) belirlenmiștir. Kolüviyal toprakların organik madde içerikleri \%0.86-2.33 ile en dar değişim aralığı sergilemiştir. Alüvyal topraklar, akarsu tarafından tașınıp depolanan 
genç topraklardır. Mineral bileșimleri toprak gelișimi sırasında erozyon ve birikimlere bağlıdır (Dengiz, Göl, Ekberli ve Özdemir, 2009). Bölge içerisinde \%5.78'lik bir kısmı kaplamaktadır. \% $\mathrm{CaCO}_{3}$ içeriği en düşük kireçsiz Kahverengi Orman (\%1.01-2.76), en yüksek ise Kahverengi Orman toprak (\%1.1255.57) grubunda belirlenmiștir. Kahverengi Orman toprakları kireç içeriği yüksek ana materyal üzerinde olușmuș profilleri $A B C$ șeklinde olup horizonlar birbiri içerisinde geçiș halindedir. Bu toprakların bir kısmı orman, funda, mera olarak kullanııırken bir kısmı ise tarım arazisi niteliğindedir. Kireçsiz Kahverengi orman toprakları (N) șistler, sepantin ve kristal kireçtașı üzerinde orman ve çalı örtüsü altında, zayıf ile ileri derecede katmanlașmıș özelliklere sahiptir. Üst toprak profilinde koyu gri kahverengi $A$ horizonu, altında daha koyu kırmızı ve daha ağır bünyeli $B$ horizonu, altında $C$ ve $R$ ayrı ayrı veya beraber bulunan horizonlara sahiptir. Serpantin ve serpantin mesozoike sahptir. Serpantin ve bazı șistlerden ayrıșan materyal serbest kireçten yoksundur (KHGM, 1994). Kahverengi Orman toprakları arpa ve buğday yetiștiriciliğinin en fazla yapıldığı toprak grubudur. Söz konusu tahıl yetiștiriciliğinin yaklașık \% $20^{\prime}$ lik kısmı bu grup topraklarda olup kireç içerikleri çavdar ve yulaf yetiștirilen topraklara göre daha yüksek belirlenmiștir.

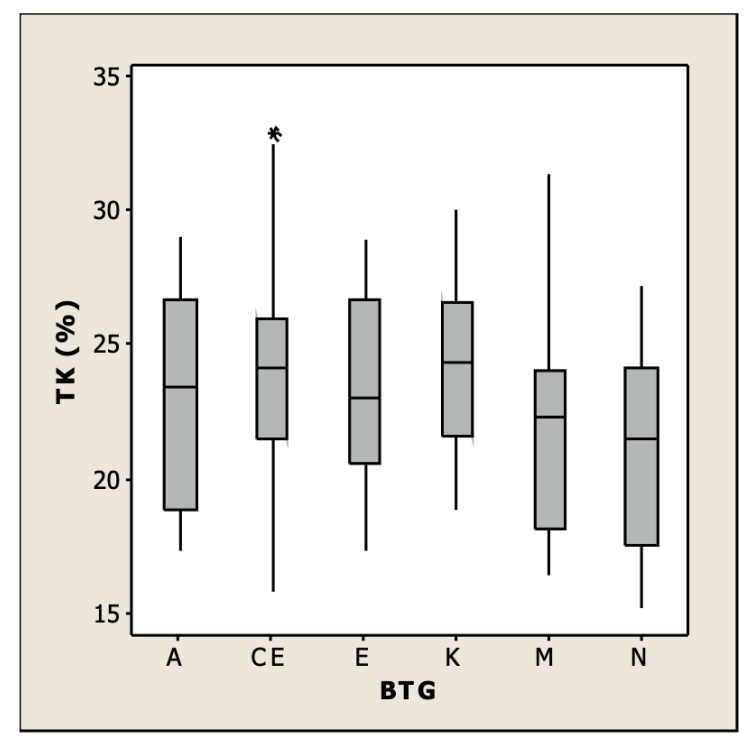

Șekil 3. Tarla kapasitesi ve Solma noktası'nın toprak gruplarına göre dağılımları

Figure 3. Field capacity and wilting point distributions according to soil groups

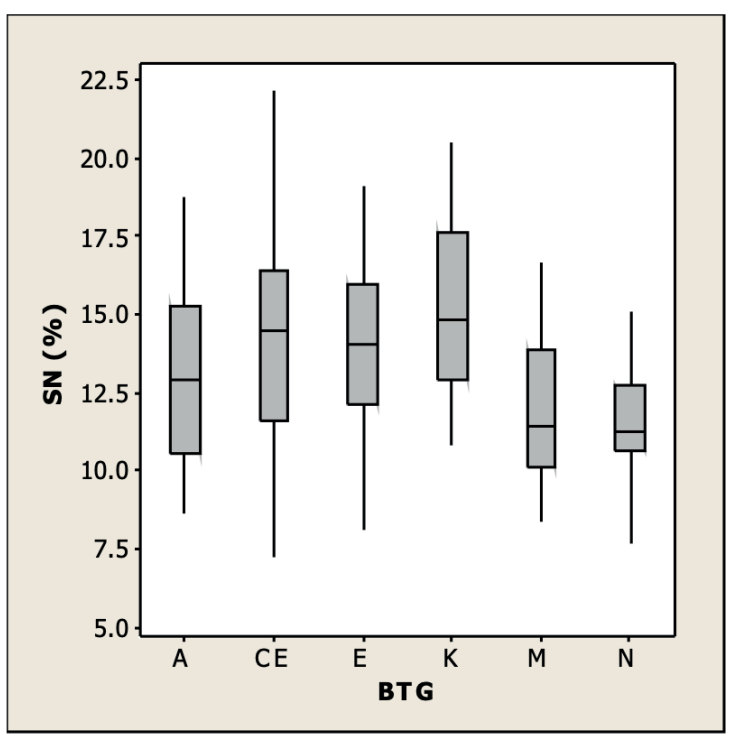

Tahıl yetiștirilen alanların tarla kapasitesi ve solma noktası içeriklerinin BTG'ye göre dağılımları Șekil 3'de belirtilmiștir. Toprakların tarla kapasitesi ve solma noktası içerikleri değișim aralığı en geniș Kestanerengi topraklarda (\% 15.80-32.80; \% 7.23-21.80) olması kaynaklı minimum ve maksimum değerlerde söz konusu toprak grubunda belirlenmiștir.

Kestanerengi topraklar (CE) kalsifikasyon sonucu olușmuș kalsiyum içeriği ve baz doygunluğu yüksek, B horizonunun rengi koyu kahverengi veya kırmızımsı kahverengi özelliğe sahip topraklardır. Bu topraklar orta derecede kalkerli olup $\mathrm{CaCO}_{3}$ miktarı profil derinliklerine doğru artıș gösterir (KHGM, 1994). Bölgede \%13.46'ık bir kısmı kaplamaktadır. Kireçsiz Kahverengi Orman topraklarının TK (\%15.2427.17) ve SN içerikleri (7.65-18.95) diğer toprak gruplarına göre daha düșük seviyelerdedir. Genel olarak organik madde içeriğininde diğer toprak gruplarına göre daha düșük seviyelerde olması TK ve SN'ninde düșük olmasının bir sebebidir. Tüm toprak grupları için söz konusu özelliklerin değişimi birbirine benzemektedir. Tarla kapasitesinin artması solma noktasındada artışlara neden olmaktadır. Genel olarak tüm tahıl ürünleri için Kestanerengi topraklarda yetiștiriciliğin daha fazla olduğu belirlenmiș ve bu toprakların su tutma özelliklerinin birbirinden oldukça farklı olduğu belirlenmiștir. 
Ekstrakte edilebilir katyonların ( $\mathrm{K}, \mathrm{Ca}, \mathrm{Mg})$ toprak gruplarına göre dağılımları Șekil 4'de belirtilmiștir. Tümtoprakguplarındagenelolarak $\mathrm{K}$ içerikleri benzer değișim aralığı içerisinde olup noksanlık problemi görülmemektedir. $\mathrm{K}$ içeriği en yüksek Alüviyal $\left(998 \mathrm{mg} \mathrm{kg}^{-1}\right)$ en düșük ise Kırmızı Kahverengi Akdeniz $(280$ mg $\mathrm{kg}^{-1}$ ) topraklarında belirlenmiștir. Toprakların $\mathrm{Ca}$ içeriği incelendiğinde en yüksek değișim aralığı Kırmızı Kahverengi Akdeniz (1067-8917 $\mathrm{mg} \mathrm{kg}^{-1}$ ), en düșük ise kireçsiz Kahverengi Orman topraklarında (2902-7626 mg kg-1)'da bulunmuștur. Alüviyal, Kestanerengi, Kırmızı Kahverengi Akdeniz, Kolüvyal, Kahverengi Orman topraklarında düşük seviyelerde $\mathrm{Ca}$ noksanlığı görülebilirken Kireçsiz Kahverengi Orman topraklarında rastlanılmamıștır. Alüviyal topraklar dıșında (1137-6068 mg kg-1) diğer gruplarda Ca içeriği dahayüksek seviyelerdedir. Çavdar ve yulaf yetiștiriciliği genellikle Alüviyal, Kestanerengi, Kırmızı Kahverengi Akdeniz, Kolüvyal toprak gruplarındadır.

Toprakların en düșük $\mathrm{Mg}$ içeriklerin tüm toprak gruplarında benzerlik gösterirken en fazla noksanlığın görüldüğü grup Kahverengi Orman toprakları (137-575 mg kg-1)'dır. Kahverengi Orman toprakları dișındaki diğer topraklarda maksimum $\mathrm{Mg}$ seviyeleri birbirine oldukça yakın seviyelerdedir. Kahverengi Orman topraklarının $\mathrm{K}$ ve $\mathrm{Ca}$
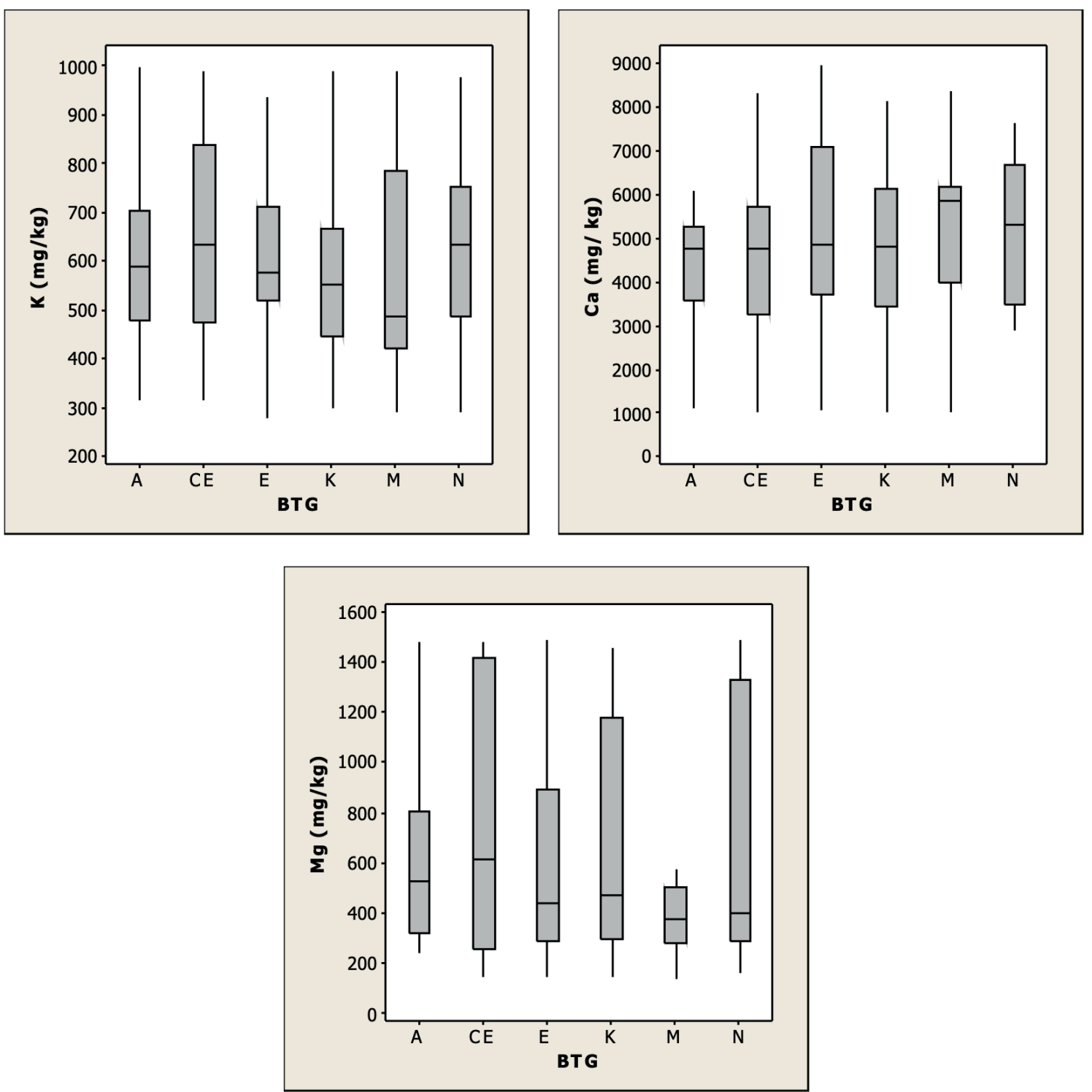

Șekil 4. Ekstrakte edilebilir katyonların toprak gruplarına göre dağılımı

Figure 4. Distribution of extractable cations according to soil groups 
içeriklerinde noksanlıklar görülmezken, $\mathrm{Mg}$ seviyelerinin noksan olması gübreleme kaynaklı olabilmektedir. Tarla bitkilerinde gübreleme amaçlı fosfatlı, amonyumlu, nitratlı, kalsiyumlu gübreler kullanılmaktadır (Baydar, 2018). K, $\mathrm{Ca}$ ve $\mathrm{Mg}$ içerikleri yönünden kestane rengi toprakların değișim aralıkları oldukça geniștir. $\mathrm{Bu}$ toprak grubunun baz doygunluklarının yüksek olması söz konusu elementlerinin yüksek belirlenmesinin bir etkisidir. Kestanerengi topraklarda en fazla buğday yetiștiriciliğinin yapıldığı gözlenmektedir. Ayrıca Mg noksanlığının görüldüğü toprak grubu olan Kahverengi Orman topraklarında en fazla Arpa yetiștiriciliği yapılmaktadır.
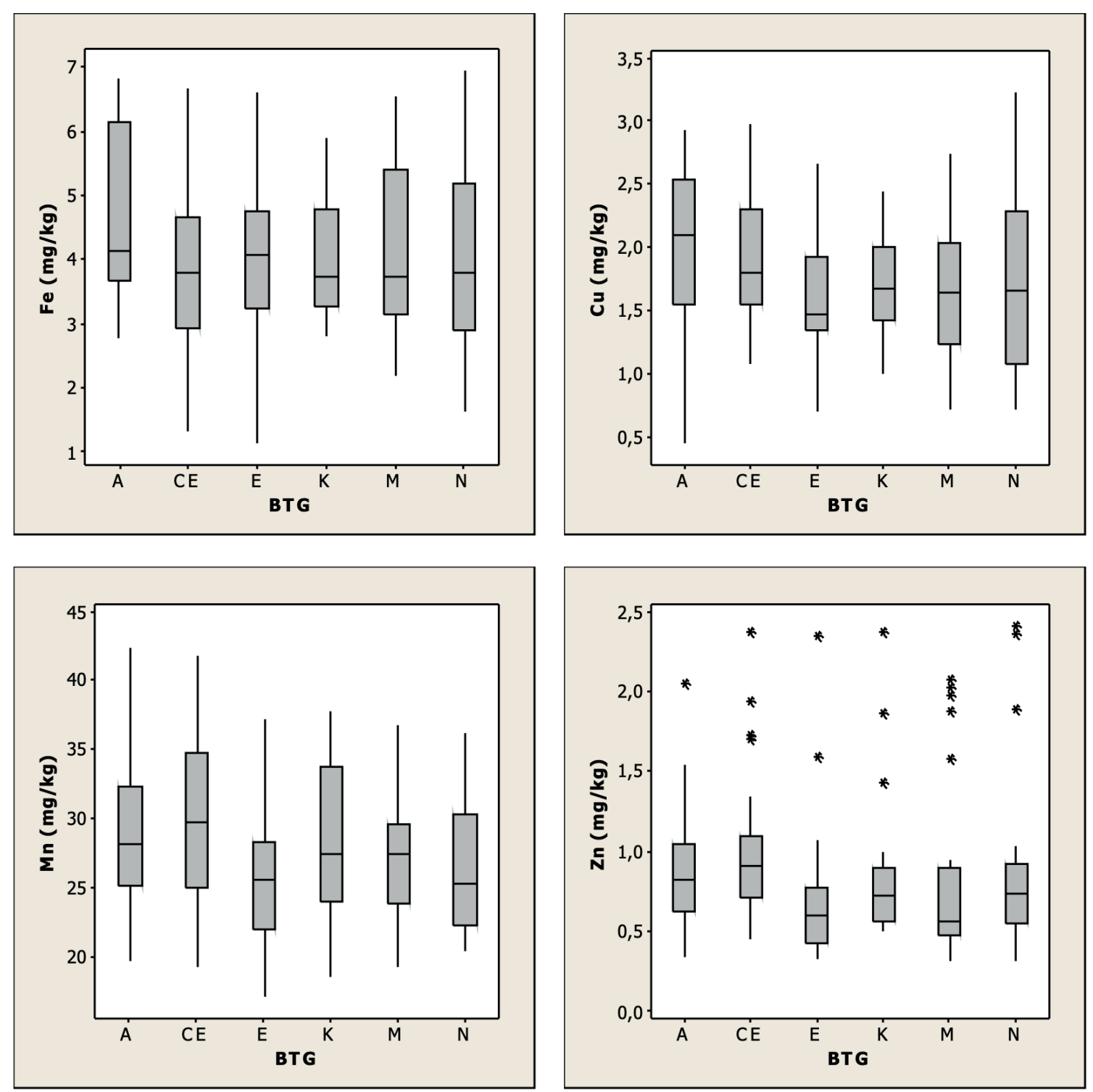

Șekil 5. Ekstrakte edilebilir mikro element içeriklerinin toprak gruplarına göre dağılımı

Figure 5. Distribution of extractable microelements according to soil groups 
düșük $\mathrm{Cu}$ içeriği Alüvyal $\left(0.45 \mathrm{mg} \mathrm{kg}^{-1}\right)$ en yüksek ise Kireçsiz Kahverengi Orman (3.22 $\mathrm{mg} \mathrm{kg}^{-1}$ ) topraklarında belirlenmiștir. Değișim aralığı en dar Kolüvyal (1.00-2.43 mg kg-1) topraklarda iken en çok değișkenlik gösteren grup Alüvyal topraklar $\left(0.45-2.93 \mathrm{mg} \mathrm{kg}^{-1}\right)$ olmuștur.

Mn içerikleri en düșük Kırmızı Kahverengi Akdeniz (17.04 mg kg-1), en yüksek ise Alüvyal (42.305 $\mathrm{mg} \mathrm{kg}^{-1}$ ) topraklarda belirlenmiștir. Yeterli seviyelerde $\mathrm{Mn}$ içeren toprakların maksimum değerlerine göre dağılımları $\mathrm{A}>\mathrm{CE}>\mathrm{K}>\mathrm{M}>\mathrm{N}>\mathrm{E}$ șeklinde sıralanmıştır. Tüm toprak gruplarında genel olarak Zn noksanlığı görülmekte olup genel dağılımdan sapan aykırı değerler bulunmuștur. En düșük Zn içerikleri (0.312-2.072 $\mathrm{mg} \mathrm{kg}^{-1}$ ) Kahverengi Orman toprakları grubunda belirlenmiștir. Yüksek kireç içeriğinin fosfor ve çinko alınabilirliği üzerinde negatif etki gösterdiği Kacar, Taban, Alpaslan ve Fuleky (1998) tarafından bildirilmiș olup Kahverengi Orman toprakların $\% \mathrm{CaCO}_{3}$ içerikleri yüksek seviyelerde bulunmuştur (Şekil 2). Tümsavaș ve Aksoy (2008) Kahverengi Orman toprakları üzerinde yürüttükleri çalışmada; pH'yı nötr-hafif alkalin, ekstrakte edilebilir $\mathrm{Zn}$ içeriğini orta, $\mathrm{K}$ ve $\mathrm{Fe}$ içeriklerini yeterli, $\mathrm{Mn}$ ve $\mathrm{Cu}$ içeriklerini ise yüksek düzeyde belirlemișlerdir. Çalıșmada elde edilen sonuçlar benzerlik göstermiștir.

\section{Sonuçlar}

Tahıl yetiștirilen ve alanın \%64.97'lik kısmını olușturan Alüvyal, Kestanerengi, Kırmızı Kahverengi Akdeniz, Kolüvyal, Kahverengi Orman, Kireçsiz Kahverengi toprakların verimlilik durumlarına göre; bünye sınıfı, orta- orta ince- ince aralıklardadır. Alandaki topraklar nötr-hafif alkali karakterde değișim göstermekte olup tuzluluk problemi bulunmamaktadır. Kireç içerikleri oldukça değișkenlik gösteren tahıl yetiștirilen toprakların \%56.4'lük kısmı az seviyede organik madde içermektedir. Tarla kapasitesi içerikleri \%15.24- 32.80 olan toprakların solma noktası ise \%7.23- 22.12 arasındadır. Topraklarının \%5'inde $\mathrm{Ca}, \% 7.85$ 'inde $\mathrm{Mg}$, $\% 42$ 'sinde Zn noksanlığına rastlanırken $\mathrm{Mn}$ ve $\mathrm{Cu}$ yeterli, $\mathrm{K}$ ve Fe yeterli- fazla seviyelerde de belirlenmiștir.
Topraklardaki pH ve EC değișim aralı̆ı en geniș Kolüvyallerde belirlenmiștir. EC içerikleri incelendiğinde tüm toprak grupları için belirlenen ortanca değerler birbirine oldukça yakın iken en düșük değișim aralı̆ı̆ ve değerler Kırmızı Kahverengi Akdeniz topraklarında belirlenmiștir. Tarla kapasitesi ve solma noktası içeriklerinin değișim aralığı en geniș Kestanerengi topraklarında bulunmuștur. Besin elementleri içerikleri yönünden de kestane rengi büyük toprak gruplarında yapılan yetiştiriciliklerde noksanlıklara rastlanımamaktadır. En fazla Mg ve Zn noksanlığının görüldüğü grup Kahverengi Orman toprakları olarak belirlenmiștir. Ayrıca tüm toprak gruplarında genel olarak $\mathrm{Zn}$ noksanlığı görülmektedir.

Toprak gruplarına göre yetiștirilen tahıl ürünleri incelendiğinde; yulaf ve çavdargenellikle Kırmızı Kahverengi Akdeniz ve Kestanerengi topraklarda, arpa Kahverengi Orman, buğday ise Kestanerengi topraklarda yetișmektedir. Arpa ve Buğdayın en az yetiștiricik yapıldığı toprak grubu Alüvyal ve Kolüvyallerdir. Tüm tahıl grupları için en yaygın olarak yetiştiricilik yapılan toprak grubu Kestanerengi olarak belirlenmiştir.

Çalışma sonucunda; bitkiye yarayıșlı makro ve mikro besin elementleri yönünden Zn dıșında genel anlamda yeterli olarak dağılım gösteren toprakların verimliliği etkileyecek noksanlıklar belirlenmemiștir. Isparta ili tahıl yetiștirilen alanların düșük olan organik madde içeriklerinin arttırılması ve Zn'li gübreleme programlarının daha dikkatli yapılması suretiyle daha verimli tahıl ürünlerinin yetiștirilebileceği yapılan çalıșma sonuçlarına göre öngörülmektedir.

\section{Kaynaklar}

Aydemir, O., Akgül, M., Canbolat, M. Y., \& Işıldar, A. A. (2005). Toprak Bilgisi. Ziraat Fakültesi Yayın No:10, Ders Notu Yayın No:1.

Aylar, F. (2015). Budaközü Çayı Havzası Topraklarının Genel Özellikleri ve Bașlıca Sorunları. Dumlupınar Üniversitesi Sosyal Bilimler Dergisi, (17).

Azlan, A., Aweng, E. R., Ibrahim, C. O., \& Noorhaidah, A. (2012). Correlation Between Soil Organic Matter, Total Organic Matter and Water Content with Climate and Depths of Soil at Different Land Use in Kelantan, Malaysia. Journal of Applied Sciences and Environmental Management 16(4), 353-358.

Baldock, J. A. (2007). Composition and Cycling of Organic Carbon in Soils. P. Marschner, P., 
Rengel, Z. (Ed.), In Nutrient Cycling in Terrestrial Ecosystems (1-36). Springer, Verlag Berlin Heidelberg.

Bașar, H. (2001). Bursa Ili Topraklarının Verimlilik Durumlarının Toprak Analizleri lle Incelenmesi. Uludağ Üniversitesi Ziraat Fakültesi Dergisi 15, 69-83.

Bașaran, M., \& Okant, M. (2005). Bazı Toprak Özelliklerinin Eldivan Yöresinde Yetiștirilen Kirazların Beslenme Durumu Üzerine Etkisi. Tarım Bilimleri Dergisi 11(2), 115-119.

Bașayiğit, L., Șenol, H., \& Müjdeci, M. (2008). Isparta Ili Meyve Yetiștirme Potansiyeli Yüksek Alanların Bazı Toprak Özelliklerinin Coğrafi Bilgi Sistemleri ile Haritalanması. Süleyman Demirel Üniversitesi Ziraat Fakültesi Dergisi 9(2), 1-10.

Baydar, H. (2018). Tarla Bitkilerine Giriș. https:// suleyildar.fileswordpress.com/ 2014/ 12/tarlabitkilerine-giris-16112012.pdf .

Bilgin, A., \& Kara, V. (2019). Isparta Yöresinde Yerleșim Alanlari Seçimi Açısından Jeolojik Tehlikeler. http://www.imo.org.tr/resimler/ ekutuphane/pdf/11101.pdf.

Boydak, Ç., \& Erdal, İ. (2011). Isparta Yöresi Kiraz Bahçeleri Topraklarının Bitkiye Yarayıșlı Demir Miktarlarının Belirlenmesinde DTPA ve EDTA Test Yöntemlerinin Karșılaștırılması. Süleyman Demirel Üniversitesi Ziraat Fakültesi Dergisi 6(1), 22-27.

Budak, M., Günal, H., Çelik, İ., Acır, N., \& Sırrı, M. (2018). Dicle Havzası Toprak Özelliklerinin Yersel Değișimlerinin Jeoistatistik ve Coğrafi Bilgi Sistemleri ile Belirlenmesi ve Haritalanması. Türkiye Tarımsal Araștırmalar Dergisi 5(2), 103115.

Corine. (2018). Arazi Örtüsü İstatistik Verileri. http:// corinetarim orman gov.tr/corine.

Çelik, Y. (2006). Isparta Ovasi Mühendislik Jeolojisi Haritasi Veri Tabani Hazırlanması (Yüksek Lisans Tezi). Süleyman Demirel Üniversitesi Fen Bilimleri Enstitüsü, Jeoloji Mühendisliği Anabilim Dalı.

Çimrin, K. M., \& Boysan, S. (2006). Van Yöresi Tarım Topraklarının Besin Elementi Durumları Ve Bunların Bazı Toprak Özellikleriyle Ilișkileri. Yüzüncü Yıl Üniversitesi Ziraat Fakültesi Tarım Bilimleri Dergisi 16, 105-111.

Demir, G., \& Erdal, İ. (2016). Antalya yöresinde domates yetiștirilen seralarda bor düzeylerinin bazı toprak, yaprak ve meyve analiz sonuçlarıyla değerlendirilmesi. Toprak Bilimi ve Bitki Besleme Dergisi 4(2), 42-48.

Dengiz, O. (2010). Morphology, Physico-Chemical Properties and Classification of Soils on Terraces of the Tigris River in the South-East Anatolia Region of Turkey. Journal of Agricultural Sciences 16 (3), 205-212.

Dengiz, O., Göl, C., Ekberli, İ., \& Özdemir, N. (2009). Farklı Aluviyal Teras Șekilleri Üzerinde Olușmuș Toprakların Dağılımı ve Özelliklerin Belirlenmesi. Anadolu Tarım Bilimleri Dergisi24(3), 184-193.

Demiralay, i. (1993). Toprak Fiziksel Analizleri. Atatürk Üniversitesi Ziraat Fakültesi Yayınları.
Diallo, D., \& Mariko, A. (2013). Field capacity (FC) and Permanent Wilty Point (PWP) of Clay Soils Developed on Quaternary Alluvium in Niger River Loop (Mali). International Journal of Engineering Science 3, 1085-1089.

Doğan, A., \& Erdal, ì. (2018). Burdur Ili Tahıl Yetiștirilen Toprakların Verimlilik Durumlarının Belirlenmesi.Toprak Bilimi ve Bitki Besleme Dergisi 6(1), 39-45.

FAO. (1990). Micronutrient, Assesment at the Country Level: An international study. FAO Soils Bulletin, 63. Rome

Follet, R. H. (1969). Zn. Fe. Mn and Cu in Colorado Soils. PhD. Dissertation. Colo. State Univ.

Güçdemir, İ. H. (2006). Türkiye Gübre ve Gübreleme Rehberi. Güncelleștirilmiș ve Genișletilmiș 5 . baskı. Tarımsal Araștırmalar Genel Müdürlüğü, Toprak ve Gübre Araștırma Enstitüsü Müdürlüğü Yayınları.

Güneș, A., Aktaș, M., İnal, A., \& Alpaslan, M. (1996). Konya Kapalı Havzası Topraklarının Fiziksel ve Kimyasal özellikleri. A.Ü. Ziraat Fakültesi Yayınları.

Howitt, D., \& Cramer, D. (2011). Introduction to SPSS Statistics in Psychology: for Version 19 and Earlier (Fifth edition), Pearson Education Limited, London.

Kacar, B. (2009). Toprak Analizleri. Nobel Yayın Dağıtım.

Kacar, B., Taban, S., Alpaslan, M., \& Fuleky, G. (1998). Zincphosphorus Relationship in the Dry Matteryield and The Uptake of Zn, P, Fe and Mnof Rice Plants (Oryzasativa L.) as Affected by the Total Carbonate Content of The Soil. 2nd International Zinc Symposium, Abstracts, s. 20, 2-3 October, Ankara, Turkey.

Karaatlı, M. (2010). Verilerin Düzenlenmesi ve Gösterimi, Editör: Kalaycı, Ş. SPSS Uygulamalı Çok Değișkenli istatistik Teknikleri, Asil Yayın Dağıtımı Ltd. Ști Ankara, 2-47.

Karahan, G., Erșahin, S., \& Öztürk, H. S. (2014). Toprak Koșullarına Bağlı Olarak Tarla Kapasitesi Dinamiği. Gaziosmanpașa Üniversitesi Ziraat Fakültesi Dergisi 30(1), 1-9.

KHGM. (1994). Isparta Illi Arazi Varlığı. Köy Hizmetleri Genel Müdürlüğü Yayınları, İl raporu, 32, Ankara.

Lindsay, W. L., \& Norvell, W. A. (1969). Development of a DTPA Micronutrient Soil Test. Soil Science Society of American Proceeding 35, 600-602.

Maas, E. V. (1986). Salt Tolerance of Plants. Applied Agricultural Research 1, 12-25.

Meteoroloji Genel Müdürlüğü (MGM), 2018. http:// www. mgm.gov.tr/veridegerlendirme/yilliktoplam-yagis verileri .aspx \#sfU.

Mohd-Aizat, A., Mohamad-Roslan, M. K., Sulaiman, W. N. A., \& Karam, D. S. (2014). The Relationship Between Soil pH and Selected Soil Properties in 48 Years Logged-over Forest. International Journal of Environmental Sciences 4(6), 1129.

Rawls, W. J, Brakensiek, D. L., \& Saxton, K. E. (1982). Estimation of Soil Water Properties. Transactions ASAE 25(5), 1316-1328. 
Rice, T. J. (1999). Liming of Vineyard Soils. Practical Winery and Vineyard Magazine. https:// digitalcom mons.calpoly.edu/cgi/viewcontent. cgi?referer=https://www.google.com. tr/\&httpsredir $=1 \&$ article $=1017 \&$ context $=$ ersc_fac

Richards, L. A. (1954). Diagnosis and Improvement Saline and Alkaline Soils. U.S. Dep. Agr. Handbook 60.

Schachtschabel, P., Blume, H. P., Brümmer, G., Hartge, K. H., \& Schwertmann, U. (2001). Toprak Bilimi (Çevirenler: Özbek H, Kaya Z, Gök M, Kaptan H.). Ç.Ü. Ziraat Fak. Genel Yayın No: 73. Ders Kitapları Yayınları.

Sünal, S., Dikmen, Ü., Erșahin, S., Așkın, T., Özenç, D. B., Tarakçıŏlu, C., Korkmaz, K., Așkın, T., \& Kutlu, T. (2018). Orta Karadeniz Bölgesi KolüvyalAlüvyal Topraklarında Bazı Kimyasal Toprak Özelliklerinin Uzaysal Değișkenliği. Toprak Bilimi ve Bitki Besleme Dergisi 6(1), 61-66.

TOVEP (1991). Türkiye toprakları verimlilik envanteri. T.C. Tarım Orman ve Köy İşleri Bakanlığı Köy Hizmetleri Genel Müdürlüğü.
TÜiK (Türkiye istatistik kurumu). (2018). Bitkisel Üretim Istatistikleri. http://www.tuik. gov.tr/ PreTablo.do?alt_id=1001.

Tümsavaș, Z., \& Aksoy, E. (2008). Kahverengi Orman Büyük Toprak Grubu Topraklarının Verimlilik Durumlarının Belirlenmesi. Uludağ Üniversitesi Ziraat Fakültesi Dergisi 22(1), 43-54.

Turan, M. A., Katkat, A. V., Özsoy, G., \& Taban, S. (2010). Bursa ili Alüviyal Tarım Topraklarının Verimlilik Durumları Ve Potansiyel Beslenme Sorunlarının Belirlenmesi. Uludağ Üniversitesi Ziraat Fakültesi Dergisi 24(1), 115-130.

U.S Salinity Laboratory Staff. (1954) Diagnosis and Improvement of Salina and Alkali Soils. Agricultural Handbook, 60, U.S.D.A.

Wilding, L. P. (1985). Spatial Variability: Its Documentation, Accommodation and Implication to Soil Surveys, 166-194p. In D.R. Nielsen and J. Bouma (eds.). Soil Spatial Variability: Pudoc, Wageningen, Netherlands.

Yılmaz, H., Demircan, V., \& Dernek, Z. (2006) Isparta İlinin Tarımsal Yapısı, Üretimi ve Gelișme Potansiyeli. SDÜ Ziraat Fakültesi Dergisi 11(2), 1-16. 